\title{
E-Module of Cost Estimating Course in Building Construction Vocational Undergraduate Program Faculty of Engineering Universitas Negeri Jakarta
}

\author{
Riyan Arthur ${ }^{1, *}$, Riza Nur Dwi, Lenggogeni \\ Universitas Negeri Jakarta, Jl. R.Mangun Muka Raya, Jakarta Timur, Daerah Khusus Ibukota Jakarta 13220 \\ Iarthur@unj.ac.id* \\ * corresponding author
}

\begin{abstract}
\begin{tabular}{l|l} 
ARTICLE INFO ABSTRACT & ART
\end{tabular}
Article history

Received July 18, 2019

Revised August 20, 2019

Accepted November 21, 2019

Keywords

E-module

Blended learning

Estimate real cos

Vocational construction

building

This R\&D aims to develop e-modules based on blended learning in the cost estimating course. The research used the R\&D method with the 4D (four-D) model carried out through four main stages, namely define, design, development, and dissemination. The e-module development was limited only to the assessment and limited dissemination to experts or the development stage. This study used a questionnaire as a tool to test the feasibility of the instructional through expert validation and student assessment. The results obtained from Instructional experts, material, and students showed that this electronic module is suitable for use in cost estimating subject in Building Construction Vocational Undergraduate Program, Faculty of Engineering, Universitas Negeri Jakarta. However, further research is needed on the fourth stage (disseminate).

R\&D ini bertujuan untuk mengembangkan modul-e berdasarkan pada blended learning dalam kursus estimasi biaya. Penelitian ini menggunakan metode R\&D dengan model 4D, dilakukan melalui empat tahap utama, yaitu mendefinisikan, desain, pengembangan, dan diseminasi. Pengembangan e-modul hanya terbatas pada penilaian dan diseminasi terbatas untuk para ahli atau tahap pengembangan. Penelitian ini menggunakan kuesioner sebagai alat untuk menguji kelayakan pembelajaran melalui validasi ahli dan penilaian siswa. Hasil yang diperoleh dari mantan instruktur, bahan, dan siswa menunjukkan bahwa modul elektronik ini cocok untuk digunakan dalam perkuliahan RAB dalam Program Sarjana Kejuruan Konstruksi Bangunan, Fakultas Teknik, Universitas Negeri Jakarta. Namun, penelitian lebih lanjut diperlukan pada tahap keempat (diseminasi).
\end{abstract}

This is an open access article under the CC-BY license.

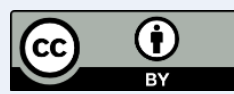

\section{Introduction}

Education defines as the effort to develop human potential through learning processes (Yuliandari, 2014). The learning process adapted to the 4.0 revolution provokes the emergence of blended learning. It is one of the learning models that incorporate two learning methods (Ghiffar et al., 2018). The illustration of conventional learning, blended learning, and e-learning relation is presented Fig. 1. Within its process, e-learning requires a module as one of the learning sources (Zaneldin et al., 2019). E-module based on blended learning has been proven effective to accelerate students' skills in many universities (Al-Samarraie \& Saeed, 2018).

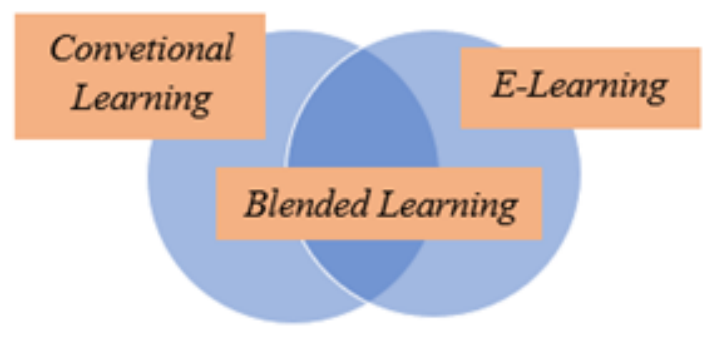

Fig. 1.Relation between Learning Models Source: (Darmawan, 2014) 
This module displays various learning that results in students' excellent skills (Bock et al., 2018; D. Prasetyo, 2015; Tampubolon et al., 2017). Besides, the implementation of collaborative learning also improve the activities and learning results of cost estimating course, primarily on the skill of architectural drawing techniques (Lasidos \& Matondang, 2015).

In addition, a learning management system (LMS) application is required to fulfill the blended learning model. One of the applications frequently used in the e-learning process is Moodle. Moodle's name comes from the emodular object-oriented dynamic learning environment (Sugihartini \& Jayanta, 2017). Moodle offers open sources that can be easily modified based on the users' needs. Besides, it can be used for free, easily accessed through http://www.moodle.org. On top of all, its features are continuously developed to support a more functional learning design (Fendy, 2017).

E-module based on blended learning is a new breakthrough that aims to support learning and teaching processes (Goh \& Zukas, 2016; Hamid et al., 2017; Hidayati, 2016) that are qualified, valid and effective (Sumandya, 2016). This module is part of the learning processes that are planned and designed to help students to achieve the learning objectives (Kuswono \& Khaeroni, 2017) independently. Besides, it provides learning instruction that organizes the materials to be used separately or with guidance (Hamid et al., 2017).

The advantages from e-module are: (1) it gives many direct feedbacks, so students' know their scores; (2) it has clear, specific, and targeted objectives that ease the delivery of the material; (3) it motivates students to learn everywhere; (4) it accelerates students' learning independence. An excellent and interesting module features are self-instructional, selfcontained, stand-alone, adaptive, and userfriendly (Gagne et al., 2005; Suparman, 2012).

However, in developing a module, there are several things to be considered, namely: (1) the lack of experts in the good e-module construction; (2) monotonous delivery of e-module can bore the students, especially when they read the materials; (3) it is not suitable for students with the bad reading habit; (4) it requires learning experts (Susanti, 2017).

Cost estimating course is one of the compulsory courses in building construction vocational, undergraduate program, faculty of engineering, Universitas Negeri Jakarta. This course discusses the fundamental of auctions, the documents related to auctions, types of a construction contract, aspects of the construction contract, work plan and its requirement, budget planning and estimation concept, worth breakdown structure, as well as the ways to calculate budget and cost estimation for simple building construction. The development of blended learning in this course aims to create workforces that master construction cost estimation and excellent vocational high school teachers, primarily for cost estimation subjects.

Cost estimation is a thorough calculation of the total cost required, starting from the preparation of the building until the building is ready to be used (Sari, 2015). In this course, students learn a systematic calculation for a building, from the volume structure calculation to the required cost to construct that building structure (Nurjannah, 2017). Therefore, learning innovation is highly essential. A suitable learning module is required as a response in this digital era. The module should not only consist of texts, but also the depiction and presentation of the materials, as well as the related digital links.

\section{Methods}

The research used a 4D model research and development method. However, this research was only limited up to the developing phase can be seen in Fig. 2.

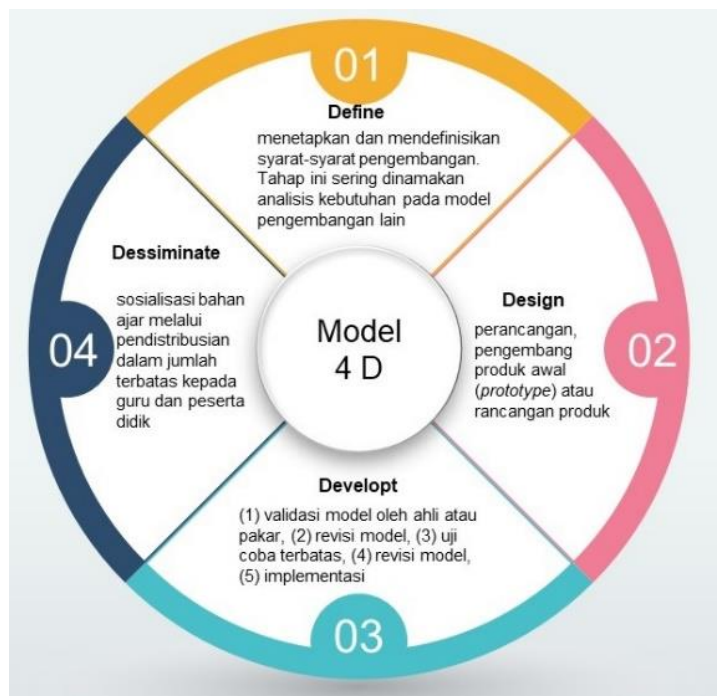

Fig. 2.4D Model. Source: (Riscaputantri \& Wening, 2018)

This research was conducted from August 2018 to July 2019 in the building construction vocational, undergraduate program, faculty of engineering, Universitas Negeri Jakarta. The feasibility test was conducted by materials and 
instructional design experts who are the lecturers in Universitas Negeri Jakarta. A lecture from building construction vocational, undergraduate program, acted as the materials validator, while lecturers from education technology undergraduate program acted as the instructional validator. The field trial was conducted in building construction vocational, undergraduate program, with 23 students who are taking a cost estimating course. The data collection was done through a 1-5 Likert scale questionnaire. The descriptive analysis of the data was conducted based on criteria displayed in Table 1. Aiken's V formula was used to measure the consistency level of the experts (Hendryadi, 2017), Table 1.
Table 1. Descriptive Product Assessment Criteria

\begin{tabular}{lll}
\hline Average Score & Category & Equivalent \\
\hline $80 \%-100 \%$ & Very valid & Very feasible \\
$66 \%-79 \%$ & Valid & Feasible \\
$56 \%-65 \%$ & Fairly Valid & Fairly Feasible \\
$40 \%-55 \%$ & Less Valid & Less Feasible \\
$<40 \%$ & Not Valid & Not Feasible \\
\hline
\end{tabular}

a. Source: (Akbar, 2013)

\section{Results}

In the define phase curriculum, conceptual, and student analysis were conducted. Curriculum and conceptual analysis resulted in learning activities with e-module and learning scenarios. From 16 meetings, there were nine classroom meetings, and seven online meetings are displayed Table 2. This planning was adaptable to the materials need that prioritizes the calculation practices. Additionally, the scenarios of nine learning with RPS and online learning are displayed in Table 3.

Table 2. Determination of Learning Activities

\begin{tabular}{|c|c|c|}
\hline \multirow[t]{2}{*}{ Learning Achievement } & \multicolumn{2}{|c|}{ Activities } \\
\hline & Classroom & Online \\
\hline Students can explain the fundamentals of construction auctions. & 1 & 1 \\
\hline Students can create documents on construction auction. & 1 & 1 \\
\hline Students can explain the types and aspects of the construction contract. & 1 & 1 \\
\hline Students can create a working plan and its requirements. & 1 & 1 \\
\hline \multicolumn{3}{|l|}{ Midterm Test } \\
\hline Total & 4 & 4 \\
\hline Students can calculate the volume of work in a simple construction project. & 2 & 1 \\
\hline Students can calculate the unit price of work in a simple construction project. & 2 & 1 \\
\hline Students can calculate the bill of quantity of work in a simple construction project. & 1 & 1 \\
\hline \multicolumn{3}{|l|}{ Final Test } \\
\hline Total & 5 & 3 \\
\hline Total & 9 & 7 \\
\hline
\end{tabular}

b. Source: Research documents

Table 3. Online Learning Scenario

\begin{tabular}{ll}
\hline & Daring \\
\hline Students & $\begin{array}{c}\text { Five days, maximum, after the classroom meeting } \\
\text { (100 minutes, minimum) }\end{array}$ \\
Access the e-learning website and log in as a student. & \\
Open the course/class assigned by the lecturer. & \\
Listen to the materials presented on the website (text, graphics, \\
\&videos). \\
Give, at least, one question related to unclear materials on the \\
provided discussion forum. \\
Give two responses to the question from other students, \\
compulsory. \\
Work on the quizzes provided on the website (in the class/course \\
assigned by the lecturer). \\
Upload the assignment. \\
\hline Lecturer \\
Check the student's presence on the website. \\
Analyze the result of the quizzes finished by the students. \\
Create a mind map for the delivery of the next materials, \\
according to the result of the quiz.
\end{tabular}


The data collected from building construction vocational, undergraduate program, faculty of engineering, Universitas Negeri Jakarta showed a decrease in excellent level students' percentage during the odd semester of $2014 / 2015,22 \%$. After that, there was an increase of $31.77 \%$, on the odd semester of the following year. However, there was a continuous decrease in the consecutive year. In the odd semester of 2016/2017, there were only $31 \%$ of students with an excellent level. Besides, on the following odd semester, there was another significant decrease; only $20.92 \%$ of students got an excellent level are displayed in Table 4.

Table 4. Students' Final Grade on Cost Estimating Course

\begin{tabular}{cc}
\hline Academic Year & Excellent (Grade A-B) \\
\hline $2017 / 2018$ & $20,92 \%$ \\
\hline $2016 / 2017$ & $31 \%$ \\
\hline $2016 / 2015$ & $31,77 \%$ \\
\hline $2015 / 2014$ & $22 \%$ \\
\hline
\end{tabular}

d. Source: building construction vocational, undergraduate program, faculty of engineering, Universitas Negeri Jakarta

On the design phase, indicators, and design of the initial look of the module were created. After that, they were uploaded on the LMS. Additionally, the third phase, develop, covering the product initial design, validity test by the experts, revision on the design, product trials, feasibility test by teachers, practicality and feasibility tests by students, research data processing, and the final revision. The last phase in the $4 \mathrm{D}$ model is disseminated. It is the procedure to distribute the successfully constructed product which has passed the validity test.

The instructional design expert's validation was completed by three lecturers from the education technology undergraduate program, faculty of education science, Universitas Negeri Jakarta. Those experts validated the e-module through the ptbunj.com website. The result determined the feasibility of the e-module for the learning process.

The general indicators used for the instructional validation involved the display, program, and language. According to Table 5, the display indicators got $72 \%$ score, the program and compatibility indicators got $76,67 \%$ score, while the language and communication indicator got $76.67 \%$ score. Thus, the module is feasible. The results of instructional validation are shown in Table 5.
Table 5. Results of instructional Validation

\begin{tabular}{lcccc}
\hline \multicolumn{1}{c}{ Indicators } & $\mathbf{\% V 1}$ & $\mathbf{\% V 2}$ & $\mathbf{\% V 3}$ & Total \\
\hline Display & $78 \%$ & $74 \%$ & $64 \%$ & $72 \%$ \\
$\begin{array}{l}\text { Program \& } \\
\begin{array}{l}\text { Compatibility } \\
\text { Language \& }\end{array}\end{array}$ & $88 \%$ & $76 \%$ & $66 \%$ & $76,67 \%$ \\
$\begin{array}{l}\text { Communication } \\
\text { Total }\end{array}$ & & $83,3 \%$ & 76,7 & $76,67 \%$ \\
\hline
\end{tabular}

The learning materials experts' validation aimed to reveal the experts' opinion as the fundamental to revise and improve the module's materials quality. The validator for the materials was two lecturers from building construction vocational, undergraduate program, faculty of engineering, Universitas Negeri Jakarta. The result of the validation of the material is presented in Table 6.

Table 6. Results of Materials Validation

\begin{tabular}{lccc}
\hline \multicolumn{1}{c}{ Indicators } & $\% \mathbf{V 1}$ & $\% \mathbf{V 2}$ & $\begin{array}{c}\text { Total Per- } \\
\text { centage }\end{array}$ \\
\hline $\begin{array}{l}\text { Learning } \\
\text { objectives }\end{array}$ & $100 \%$ & $86,7 \%$ & $93,33 \%$ \\
$\begin{array}{l}\text { Materials } \\
\text { delivery }\end{array}$ & $80 \%$ & $86,7 \%$ & $83,33 \%$ \\
$\begin{array}{l}\text { Mterials Choice } \\
\text { Total }\end{array}$ & $86,7 \%$ & $100 \%$ & $93,33 \%$ \\
Percentage & & & $90 \%$ \\
\hline
\end{tabular}

e. Source: results of materials validation

Based on the materials experts' validation, learning objectives, Materials delivery, and materials choice earned a score of $93.33 \%$, $83.33 \%$, and $93.33 \%$, respectively. Therefore, the e-module for the cost estimating course is feasible to be used in the learning process. The suggestions given by the experts for the emodule are shown in Table 7.

Table 7. Experts suggestions for the e-module of cost estimating course

\begin{tabular}{|c|c|c|}
\hline No & $\begin{array}{c}\text { Design before the Revi- } \\
\text { sion }\end{array}$ & $\begin{array}{l}\text { Design after } \\
\text { the Revision }\end{array}$ \\
\hline \multicolumn{3}{|c|}{ Instructional Expert Review } \\
\hline 1. & $\begin{array}{l}\text { There were no instructions } \\
\text { for the materials used for the } \\
\text { conventional and e-learning. }\end{array}$ & $\begin{array}{l}\text { There are } \\
\text { instructions } \\
\text { uploaded and } \\
\text { located below } \\
\text { the RPS. }\end{array}$ \\
\hline 2. & $\begin{array}{l}\text { The font used for the } \\
\text { materials explanation was } \\
\text { not suitable. The good font } \\
\text { for that material is Sanserif } \\
\text { (without hook). }\end{array}$ & $\begin{array}{l}\text { The font has } \\
\text { been revised to } \\
\text { be easily read. }\end{array}$ \\
\hline 3. & $\begin{array}{l}\text { There was too many } \\
\text { explanation in one slide. }\end{array}$ & $\begin{array}{l}\text { The slides have } \\
\text { been divided, so }\end{array}$ \\
\hline
\end{tabular}


they are no longer full of explanation.

\begin{tabular}{lll}
\hline \multicolumn{3}{c}{ Material Expert Review } \\
\hline 1. $\begin{array}{l}\text { There should be additional } \\
\text { explanation on the auctions } \\
\text { plot, completed with figures } \\
\text { or diagrams, as well as its } \\
\text { relation with cost estimating } \\
\text { course. }\end{array}$ & $\begin{array}{l}\text { The auctions } \\
\text { plot has been } \\
\text { added in the } \\
\text { module. }\end{array}$ \\
$\begin{array}{l}\text { There should be a big event, } \\
\text { followed by detailed } \\
\text { activities used as an example. }\end{array}$ & $\begin{array}{l}\text { There has been a } \\
\text { diagram made } \\
\text { fhat way, there would be an } \\
\text { explanation of the document } \\
\text { establishment process, not } \\
\text { only an explanation of the } \\
\text { content of the documents. }\end{array}$ & $\begin{array}{l}\text { documents. } \\
\text { dention }\end{array}$ \\
\hline
\end{tabular}

${ }^{\text {f. }}$ Research documents

Based on validators, the indicators of instructional design validation considered were display, program, and language. On the other hand, the results of the materials validity analysis from the instructional experts are shown in Table 8 .

Table 8 . Results of validity from instructional design experts

\begin{tabular}{clcc}
\hline No & \multicolumn{1}{c}{ Indicators } & V & Description \\
\hline 1 & Display & 0,65 & Valid \\
2 & Program & 0,71 & Valid \\
3 & Language and & 0,71 & Valid \\
& Communication & & \\
& Average Score & 0,69 & Valid \\
\hline
\end{tabular}

g. Source: Expert Analysis on the Module

Based on the explanation above, the average score of the e-module validity is 0.69 . Thus, according to the Aiken V index, that score is considered valid $(0.4 \leq \mathrm{V} \leq 0.8)$. In other words, the three experts gave a relatively consistent score and in accordance with the indicators.

After the instructional design validation, some suggestions were obtained, such as: (1) an activity determination was made, so the students know the materials used in the classroom and in the e-learning, (2) the font choice should be carefully considered for the e-module, the best font used is sanserif (without hook), (3) the slides should be improved since it was full of explanation.

In addition, the validation of the material aimed to know the consistency and compatibility of the experts' opinions as the fundamental to revise the quality of the materials within the e-module. There were two learning materials experts involved in this research. They are Anisah, M.T. and Adhi Purnomo, M.T.; both are the lecturers in building construction vocational, undergraduate program, faculty of engineering, Universitas Negeri Jakarta. The results of the materials experts' validation are presented in Table 9.

Table 9. Results of the materials experts validation

\begin{tabular}{clcc}
\hline No & Indicators & V & Description \\
\hline 1 & Learning Objectives & 0,92 & Valid \\
2 & Material Delivery & 0,81 & Valid \\
3 & Material Choice & 0,94 & Valid \\
& Average Score & 0,89 & Valid \\
\hline
\end{tabular}

h. Source: Expert Analysis on the Module

Table 9 shows that the average score of the learning objective, material delivery and material choice is 0.89 . That score is considered very valid, according to the Aiken $\mathrm{V}$ index since $\mathrm{V}>0.8$. Consequently, the experts gave a relatively consistent score and in accordance with the proposed indicators.

The empirical eligibility test was conducted once the product had been validated by the experts. The empirical eligibility is divided into two, practicality and affectivity (Bagia \& Hidayah, 2016). However, in the empirical eligibility on the e-module development was only reviewed from the practicality. It was completed by analyzing the students' responses. The results of 23 students' responses analysis are shown in Table 10.

Table 10. Results of students' responses analysis

\begin{tabular}{|c|c|c|c|c|}
\hline No & Indicators & $\mathbf{V}$ & $\%$ & Description \\
\hline 1 & $\begin{array}{l}\text { Material } \\
\text { Presentation }\end{array}$ & 0,72 & 77,39 & Feasible \\
\hline 2 & Text & 0,76 & $80,87 \%$ & Feasible \\
\hline 3 & Design & 0,66 & $72,61 \%$ & Feasible \\
\hline 4 & $\begin{array}{l}\text { Multimedia } \\
\text { Combination }\end{array}$ & 0,61 & $69,13 \%$ & Feasible \\
\hline 5 & $\begin{array}{l}\text { Navigation } \\
\text { Button }\end{array}$ & 0,65 & 71,74 & Feasible \\
\hline 6 & Module Usage & 0,70 & 75,65 & Feasible \\
\hline 7 & $\begin{array}{l}\text { Module } \\
\text { Implementa- } \\
\text { tion }\end{array}$ & 0,71 & 76,52 & Feasible \\
\hline & verage Score & 0,69 & 74,85 & \\
\hline
\end{tabular}

The average score obtained from students' response analysis was $74.85 \%$, which means this e-module is feasible to be used. Besides, its final material validity score is 0.69 , which is classified as valid. In other words, the 23 students gave relatively consistent responses and 
in accordance with the proposed indicators. The feasibility of blended learning is empirically valid if the obtained response is $0.4 \leq \mathrm{V} \leq 0.8$.

After the theoretical and empirical feasibility test, the e-module for cost estimating course of building construction vocational, undergrad- uate program, faculty of engineering, Universitas Negeri Jakarta is considered feasible to be used. The illustration of the initial and revised version of the e-module is presented in Table 11.

Table 11. Comparison of Initial and Revised E-module

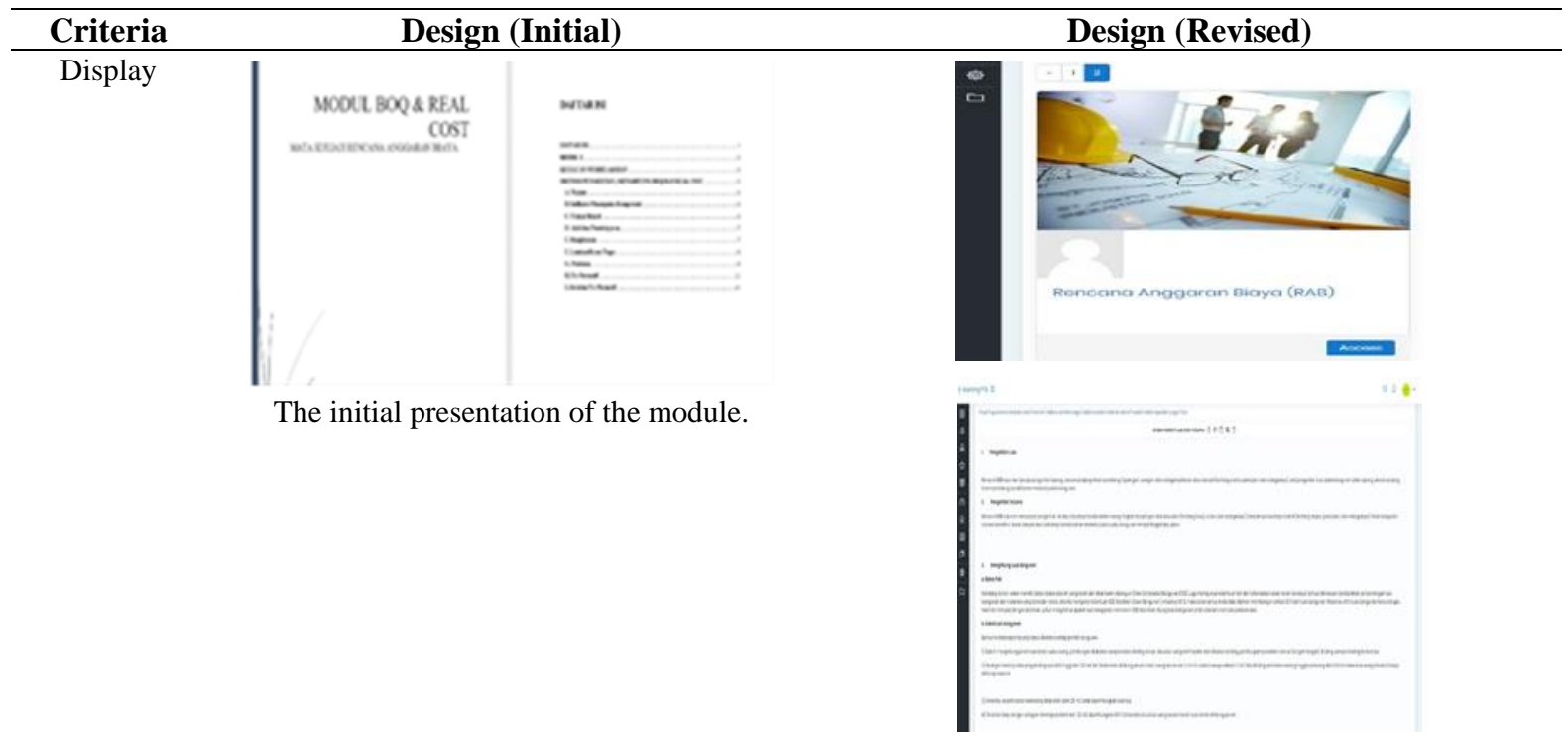

The module has been completed with the instructions, objectives, indicators, formative test materials summary.

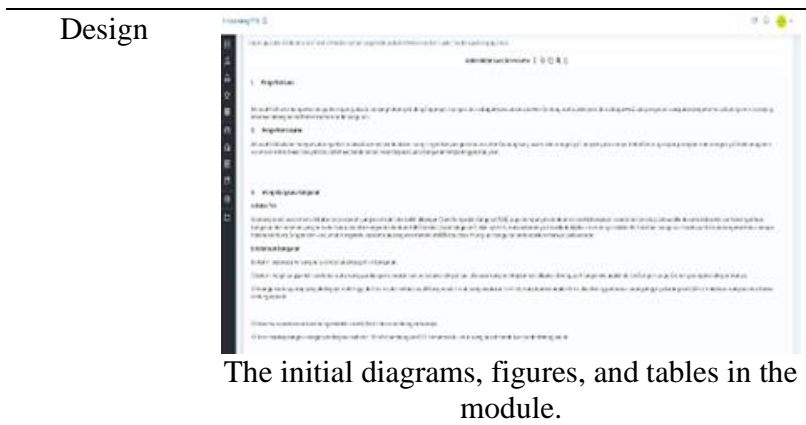

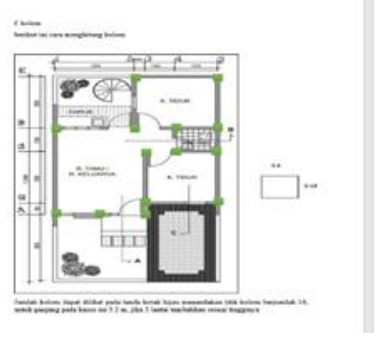

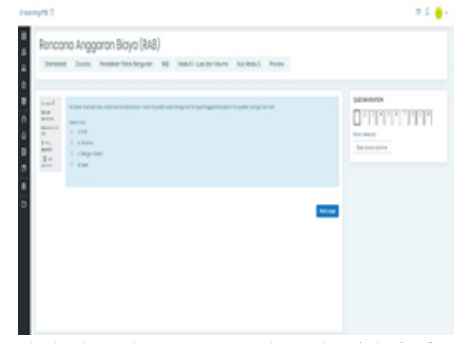

The module has been completed with info graphic explanation and randomized-items online quizzes

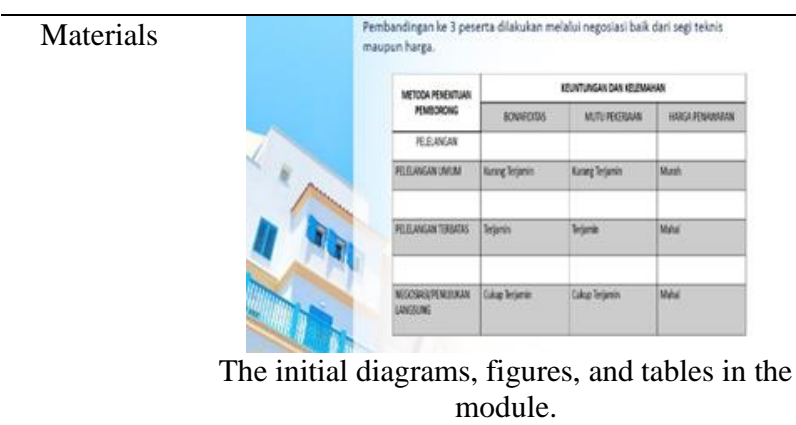
module.

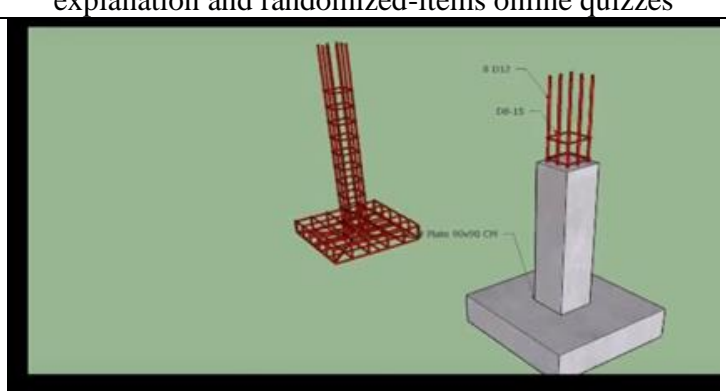

The module has been completed with hyperlinks to the animation video and presentation in the google form 
Currently, Indonesian education faces the impacts of the digital era or 4.0 industry revolution era, categorized as the challenges for universities, primarily for the lecturers as the educators (Harto, 2018).

One of the efforts used to face this revolution era is the development of blended learning for the cost estimating course in building construction vocational, undergraduate program, faculty of engineering, Universitas Negeri Jakarta. This module is one of the means to implement the blended learning model. E-module is effective and efficient in improving students' ability and shift the learning process to be interesting, as well as accelerating students' learning interest in the comfortable and diverse environment (Abdullah, 2018; Sarwandi et al., 2019).

The vocational field beginning from the planning, learning process, up to the assessment should refer to the working place based on the competencies (Arthur et al., 2019; van der Schaaf et al., 2017). This result is in line with (van Oorschot et al., 2017), who mentions that vocational learning and training requires competencies targeted and focused module on reaching a continuous assessment. Besides,(Dardiri et al., 2018; Elmunsyah, 2014) state that information and communication technology-based national education policy is the solution to improve school quality, specifically the vocational high schools in Indonesia.

The vocational education feature that emphasizes on the competence and the workforce absorption requires a meaningful learning (Sutjipto, 2019), comprehensive assessment on the competencies (Maulana et al., 2019; M. E. Prasetyo et al., 2019) and clear vision in the industrial world (Chen \& Tang, 2012).

This research also confirms that a module development requires various relevant materials resources, such as pictures, info graphics, and video (Rumanta et al., 2016; Sugiyanto et al., 2018).

\section{Conclussion}

E-module developed in blended learning for cost estimating course in building construction vocational, undergraduate program, faculty of engineering; Universitas Negeri Jakarta is in accordance with the planning. Therefore, this emodule is feasible to be used in the dissemination phase or the cost estimating course.
In this research, the development of the emodule based on blended learning still has various deficiencies that need to be improved. Thus, future researchers are recommended to do further research with larger usage and dissemination phases of the product. In the end, they are expected to reveal the affectivity of this e-module.

\section{References}

Abdullah, W. (2018). Model blended learning dalam meningkatkan efektifitas pembelajaran. Jurnal Pendidikan Dan Manajemen Islam Volume, 7(1).

Akbar, S. (2013). Instrumen perangkat pembelajaran. Remaja Rosdakarya.

Al-Samarraie, H., \& Saeed, N. (2018). A systematic review of cloud computing tools for collaborative learning: Opportunities and challenges to the blendedlearning environment. Computers and Education, 124, 77-91. https://doi.org/10.1016/j.compedu.2018.05.016

Arthur, R., Rouf, F. A., Rahmayanti, H., \& Maulana, A. (2019). Plumbing work competence instrument in the field of civil engineering. Journal of Physics: Conference Series, 1402(2), 1-6. https://doi.org/10.1088/1742-6596/1402/2/022019

Bagia, P. P. A., \& Hidayah, R. (2016). Pengembangan lembar kegiatan siswa berorientasi keterampilan proses siswa pada materi elektrolit dan non-elektrolit dan submateri reaksi oksidasi reduksi. Unesa Journal of Chemical Education, 5(2), 452-456.

Bock, A., Modabber, A., Kniha, K., Lemos, M., Rafai, N., \& Hölzle, F. (2018). Blended learning modules for lectures on oral and maxillofacial surgery. British Journal of Oral and Maxillofacial Surgery, 56(10), 956-961. https://doi.org/10.1016/j.bjoms.2018.10.281

Chen, Y., \& Tang, Y. (2012). Discussion on construction and development of local higher vocational colleges' teaching supervision. International Conference on Medical Physics and Biomedical Engineering, 33, 1149-1154. https://doi.org/10.1016/j.phpro.2012.05.189

Dardiri, A., Alfianto, I., Kuncoro, T., Suswanto, H., \& Elmunsyah, H. (2018). Entrepreneurial leadership for excellent technical and vocational education institutions. World Transactions on Engineering and Technology Education, 16(4), 441.

Elmunsyah, H. (2014). A national education policy-based ICT model for Indonesian vocational high schools (VHS). Global Journal of Engineering Education, 16(3), 136-140. 
Fendy, P. Y. (2017). Pengembangan e-learning berbasis moodle untuk peserya kursus di swift english school Yogyakarta. E-Jurnal Prodi Teknologi Pendidikan, VI(8), 813827.

Gagne, R. M., Wager, W. W., Golas, K. C., Keller, J. M., \& Russell, J. D. (2005). Principles of instructional design. Thomson Wadworth.

Ghiffar, M. A. N., Nurisma, E., Kurniasih, C., \& Bhakti, C. P. (2018). Model pembelajaran berbasis blended learning dalam meningkatkan critical thinking skills untuk menghadapi era revolusi industri 4.0. Pencegahan Dan Penanganan Kekerasan Anak: Optimalisasi Peran Pendidik Dalam Perspektif Hukum, 85-94.

Goh, A. Y. S., \& Zukas, M. (2016). Student vocational teachers: The significance of individual positions in workplace learning. Journal of Vocational Education and Training, $\quad 68(2), \quad 263-277$. https://doi.org/10.1080/13636820.2016.11 72661

Hamid, M. A., Aribowo, D., \& Desmira, D. (2017). Development of learning modules of basic electronics-based problem solving in Vocational Secondary School. Jurnal Pendidikan Vokasi, 7(2), 149. https://doi.org/10.21831/jpv.v7i2.12986

Harto, K. (2018). Tantangan dosen PTKI di era industri 4.0. Tatsqif, 16(1), 1-15.

Hendryadi, H. (2017). Validitas isi: tahap awal pengembangan kuesioner. Jurnal Riset Manajemen Dan Bisnis (JRMB) Fakultas Ekonomi UNIAT, 2(2), 169-178.

Hidayati, P. I. (2016). Optimalisasi pengembangan blended learning berbasis moodle untuk matakuliah mikrobiologi. Jurnal Inspirasi Pendidikan Universitas Kanjuruhan Malang, 6(2), 890-897.

Kuswono, K., \& Khaeroni, C. (2017). Pengembangan modul sejarah pergerakan indonesia terintegrasi nilai karakter religius. HISTORIA: Jurnal Program Studi Pendidikan Sejarah, 5(1), 31-44.

Lasidos, P. A., \& Matondang, Z. (2015). Penerapan model pembelajaran kolaboratif untuk meningkatkan aktivitas dan hasil belajar siswa pada mata pelajaran rencana anggaran biaya (RAB) siswa kelas xi kompetensi keahlian teknik gambar bangunan SMKN 2 siatas barita. Jurnal Educational Building, 1(1), 13-22.

Maulana, I., Arthur, R., \& Daryati, D. (2019). Kualitas tes kompetensi tukang aci dan plesteran berdasarkan KKNI. Jurnal Pendidikan Teknologi Dan Kejuruan, 16(2), 149-158. https://doi.org/10.23887/jptk-undiksha.v16i2.17141

Nurjannah, A. (2017). Penerapan model pembelajaran kooperatif tipe team assisted individualization (TAI) dalam mening- katkan hasil belajar siswa pada mata pelajaran rencana anggaran biaya (RAB) kelas xi tgb di SMKN Jrengik Kabupaten Sampang. Jurnal Ilmiah Pendidikan Teknik Bangunan, 03(03), 94-101.

Prasetyo, D. (2015). Pengembangan model blended learning mata kuliah interaksi manusia \& komputer menggunakan metode system development life cycle ( SDLC ). Seminar Teknologi Pendidikan, $152-162$

Prasetyo, M. E., Daryati, D., \& Arthur, R. (2019). Quality of the skill instrument install brick based on the indonesian national qualification framework (KKNI). Jurnal Taman Vokasi, 7(1), 18-22. https://doi.org/10.30738/jtv.v7i1.4769

Rumanta, M., Iryani, K., \& Retnaningsih, A. (2016). Pengembangan modul prototipe bahan ajar cetak mata kuliah pendidikan lingkungan hidup pada pendidikan terbuka dan jarak jauh: studi kasus di universitas terbuka. Jurnal Pendidikan Dan Kebudayaan, 1(2), 141. https://doi.org/10.24832/jpnk.v1i2.765

Sari, P. L. (2015). Perbedaan hasil belajar siswa antara model pembelajaran kooperatif tipe student teams achievement divisions menggunakan maket dan model pembelajaran konvensional pada mata pelajaran rencana anggaran biaya kelas. Jurnal Kajian Pendidikan Teknik Bangunan, 1(1).

Sarwandi, S., Giatman, M., Sukardi, S., \& Irfan, D. (2019). Developing mobile-based project-based learning module for project management courses in vocational education. Jurnal Pendidikan Vokasi, 9(2), 207-216. https://doi.org/10.21831/jpv.v9i2.25947

Sugihartini, N., \& Jayanta, N. L. (2017). Pengembangan e-modul mata kuliah strategi pembelajaran. Jurnal Pendidikan Teknologi Dan Kejuruan, 14(2), 221-230.

Sugiyanto, S., Wena, M., \& Isnandar, I. (2018). Developing learning materials based on training within industry (TWI) to improve the building construction student's learning outcomes. Jurnal Ilmu Pendidikan, 24(2), 80-85.

Sumandya, I. W. (2016). Pengembangan bahan ajar sistem persamaan linier berwawasan pendidikan matematika realistik berorientasi. Emasains, $V(1)$

Suparman, M. A. (2012). Desain instruksional modern. Erlangga.

Susanti, R. (2017). Pengembangan modul pembelajaran PAI berbasis kurikulum 2013 di kelas V SDN 21 Batubasa, Tanah datar. 2(1), 12-22.

Sutjipto, S. (2019). Perancangan kurikulum sekolah menengah kejuruan sebagai pranata budaya kerja. Jurnal Pendidikan 
Dan Kebudayaan, 4(1), 102-126. https://doi.org/10.24832/jpnk.v4i1.1219

Tampubolon, M. A. W., Arthur, R., \& Daryati, D. (2017). Pengembangan e-module konstruksi bangunan pada kompetensi dasar menerapkan spesifikasi dan karteristik kayu. Jurnal Pensil, 6(2).

van der Schaaf, M., Donkers, J., Slof, B., Moonen-van Loon, J., van Tartwijk, J., Driessen, E., \& Ten Cate, O. (2017). Improving workplace-based assessment and feedback by an E-portfolio enhanced with learning analytics. Educational Technology Research and Development, 65(2), 359-380. https://doi.org/10.1007/s11423-016-9496-8

van Oorschot, R. A., Szkuta, B., Ballantyne, K. N., \& Goray, M. (2017). Need for dedicated training, competency assessment, authorisations and ongoing proficiency testing for those addressing DNA transfer issues. Forensic Science International: Genetics Supplement Series, 6(August), e32-e34. https://doi.org/10.1016/j.fsigss.2017.09.013

Yuliandari, S. (2014). Pengembangan media pembelajaran berbasis multimedia interaktif pada mata pelajaran ekonomi materi jurnal penyesuaian perusahaan jasa. Jurnal Pendidikan Akuntansi (JPAK), 2(2), $1-9$.

Zaneldin, E., Ahmed, W., \& El-Ariss, B. (2019). Video-based e-learning for an undergraduate engineering course. $E$ Learning and Digital Media, 16(6), 475496. https://doi.org/10.1177/2042753019870938 